\title{
Coaching as a method for potentially reducing the risk of burnout in medical professionals
}

Sułkowska J*. ${ }^{1 \mathrm{ABDEF}}$, Kuźmicz I. ${ }^{1 \mathrm{ABDEF}}$, Malinowska-Lipień $\mathrm{I}^{1 \mathrm{ABDEF}}{ }^{\text {, }}$, Lickiewicz J. ${ }^{2 \mathrm{ABDEF}}$,
Brzostek T.

1. Department of Internal and Environmental Nursing, Faculty of Health Sciences, Jagiellonian University - Medical College, Kraków, Poland

2. Department of Psychology of Health, Faculty of Health Sciences, Jagiellonian University Medical College, Kraków, Poland

\author{
A- Conception and study design; B - Collection of data; C - Data analysis; D - Writing the paper; \\ E- Review article; F - Approval of the final version of the article; $\mathbf{G}$ - Other
}

\begin{abstract}
In their daily work, medical professionals often encounter emotionally and mentally challenging situations, such as sudden health deterioration or death of their patients.

The concern to ensure the highest possible level of healthcare and meet all the standards despite the limitations that come with working under the pressure of time, the interactions with other individuals, the physical burden and stress, as well as with the (sometimes limited) support from superiors and lack of satisfaction with salary may, as
\end{abstract}

DOI: a result, translate into a higher risk of burnout. Research indicates a potential effectiveness of coaching with respect to medical personnel. However, there are no publications available concerning nurse-oriented coaching, which would be intended to reduce the risk of burnout in this professional group. The objective of this paper is to present coaching as a method that makes it possible to reduce the risk related to burnout in medical professionals.

Keywords: coaching, burnout, medical professions, nurses, physicians

\footnotetext{
*Corresponding author:

Joanna Sułkowska

Department of Internal and Environmental Nursing, Institute of Nursing and Midwifery, Jagiellonian University Medical College, 31-501 Kraków, ul. Kopernika 25, Poland e-mail: joasia.sulkowska@doctoral.uj.edu.pl
}

Progress in Health Sciences

Vol. 7(2) 2017 pp 85-92.

Received: 10.10 .2017

Accepted: 30.10. 2017

(C) Medical University of Białystok, Poland 


\section{INTRODUCTION}

Coaching is becoming increasingly common in the area of medicine and health sciences [1-3]. It is an effective tool for strengthening the motivation of patients [4], their caregivers, and medical personnel [5]. The potential benefits for patients include, among others, higher therapy adherence [6,7], improvement of treatment results [4,6,8], increased trust in medical personnel [9], and a reduced number of admissions to medical facilities [10]. Caregivers, on the other hand, were found to experience increased emotional intelligence and job satisfaction [11] as well as an enhanced level of knowledge [12] to name only a few. Coaching interventions may also translate into higher quality of provided healthcare [6] as well as contribute to the improvement of the caregiver/patient relationship [13]. Moreover, attention is paid to the usefulness of coaching in the realm of motivation for development, increasing the feeling of causation and self-efficacy with reference to individuals who are preparing for medical careers in health promotion [14].

Work plays an important role in people's lives. Regardless of the profession chosen, one needs adequate competencies to be able to perform his/her duties at the required level. Furthermore, a crucial role is played by one's resources that help people cope with their duties despite a permanent burden. As noted by Sęk [15], burnout often affects individuals whose coping abilities in difficult situations are insufficient. Having adequate resources is important, especially in medical professions, since medical professionals often come into contact with other people not infrequently facing difficult health/life situations. Such resources help them deal with various confronting circumstances. As long as there is job satisfaction and contentment, the motivation to act remains strong.

The problem of burnout is therefore a significant issue in the area of health and social sciences. It is necessary to search for an answer to the question of whether and how it can be prevented. The significance of this problem is demonstrated through the number of publications on the subject [16-21]. Increasing attention is being paid to the interrelation between burnout and aggression towards medical personnel [22]. In the literature, it is emphasized that the key point is how employees react to verbal and non-verbal aggression [23].

Research, in which members of medical rescue teams served as respondents, indicated that the paramedics tried to calm down a verbally aggressive person in over $60 \%$ of the cases, while in approximately $13 \%$ of cases - aggressive behavior of a patient generated aggression in the paramedics [23]. Stress should therefore be laid on the bidirectionality of aggressive behaviors and their correlation with burnout. Research by Lewandowska and Litwin [24], which pertained to the assessment of burnout incidence in nurses working at the Regional Hospital of Podkarpacie Province, demonstrated that approximately $75 \%$ of the subjects considered themselves to be either burnt out or close to burnout. In this respect, it is worth pointing to the summary presented by the authors in which they claimed that it is neither age nor job seniority that had a significant effect on the percentage of nurses that felt burnt out [24].

Similar conclusions can be drawn from the preliminary research which encompassed nurses working in a hematology ward [25]. The authors [25] also underlined that age, job seniority and, amazingly enough, even additional qualifications did not significantly influence the nurses' risk of burnout. What appeared to have a negative impact was an excessive number of duties, the quality of information flow between team members, and insufficient staffing [25]. However, the authors pointed to the fact that there was an age gap in their research, concerning nurses with a seniority of 6-10 years [25].

A situation in which one's job ceases to bring satisfaction and employees are no longer as motivated to act as they used to be, due to tiredness or even exhaustion, has its consequences for all the parties involved, namely the employer, the employee, and the patient. The question is what can be done to prevent burnout. A promising solution seems to be offered by coaching targeted at medical personnel [26-28].

The paper aims to present coaching as a method that provides an opportunity to reduce the risk of burnout in medical professionals.

According to the legal acts applicable in Poland, a medical professional shall be understood to mean "a person entitled, under separate provisions, to provide health services, and a person proven to have gained professional qualifications for providing health services within a specific range or a specific field of medicine" [29].

The work of medical professionals is a demanding experience. Being in constant readiness, taking care of the necessary procedures, facing a large number of unexpected events, and sometimes receiving inadequate support from colleagues are some characteristic features describing this type of professional activity. It is often shift-based work that affects both professional and family relations. The professional role, often performed in different places and forms of employment (which entails low remuneration), is combined with other social roles. It would be desirable to fulfill the obligations associated with each role at least at a satisfactory level. This, as a consequence, may lead to various types of conflicts, which are occasionally increasing and hard to resolve. 
Medical personnel and nurses in particular are the most burnout-prone individuals from the various professional groups and specialties [30,31]. This is basically due to the fact that this problem affects those professions that require interpersonal contact with other people [31]. The intensive psychological burden and physical workload of nurses affect the quality of the healthcare provided on the one hand and may induce the development of professional stress on the other [31,32]. Particularly in the case of palliative care providers, taking care of patients, especially those aware of imminent death, who experience numerous troublesome symptoms, permanent contact with death, and the emotions of dying people and their relatives are not without an impact on medical personnel [33,34]. Similar problems may occur in employees of hospital admission rooms and $\mathrm{A} \& \mathrm{E}$ units [35].

Research to date indicates that it is necessary to develop a nurse support system as well as prevention and therapy programs, including psychological counseling services at the workplace $[32,36,37]$.

Numerous scientific reports reveal that physicians [26,27], nurses [16,25,38,39], physiotherapists [40], family assistants [41], and hospice employees [42] run the risk of suffering from burnout. The vulnerable group also includes employees of palliative or intensive care units [19].

Burnout is the body's response to chronic work-related stress, particularly in professions that are characterized by permanent contact with other people and emotional involvement in their problems. According to Maslach Ch., burnout is a "syndrome of emotional exhaustion, depersonalisation and reduced sense of personal achievement, which may develop in individuals working with other people in a specific manner" [43]. Emotional exhaustion refers to the rejection by a human being of its excessive emotional burden and the diminishing of its energy resources. Depersonalization is associated with a negative, indifferent reaction to other people, who usually receive the services provided by a given individual. Reduced sense of personal achievement refers to a decrease in one's feeling of self-competence and success at work. In the latest definition of burnout, Maslach and Leiter present this phenomenon in the following manner:

"Burnout is a psychological syndrome emerging as a prolonged response to chronic interpersonal stressors on the job. The three key dimensions of this response are an overwhelming exhaustion, feelings of cynicism and detachment from the job, and a sense of ineffectiveness and lack of accomplishment. The significance of this three-dimensional model is that it clearly places the individual stress experience within a social context and involves the person's conception of both self and others" [44].

According to Perlman B. and Hartman A.E., "burnout is a response to chronic emotional stress with three components: emotional exhaustion, lowered job productivity and over personalisation" [45]. Burisch M. defines burnout "for certain wrongly defined types of crisis" [46]. He claims that burnout is a construct present only in people's minds, constituting a blurred set of symptoms. In the socio-cognitive approach presented by Sęk H., burnout is defined as: "a set of symptoms emerging in professions where close interpersonal contact, thorough commitment and the personality traits of the practitioner are the basic professional tools determining the level of the professional service provided as well as the professional successes and failures" [47].

Kandelman, Mazars and Levy [48] conducted research on a group of 124 employees of nursing homes, where they assessed the degree of burnout and the factors that influenced the possibility of its occurrence. The protective factors included regular recreation and being a nurse [48]. The risk factors encompassed the following: aggression experienced from the subjects, the necessity to use protocols for pain assessment and death announcement, which were regarded as burdensome especially when developed by administrative employees, and the type of structure: "private profit making institution" [48].

Analysis of the results from research conducted by Shimizutani et al. in a group of 707 nurses working in a university hospital in Japan identified burnout-related factors, which were divided into three groups: personal, work-related, and patient-related [49].

The first group showed the following risk factors: quantitative and qualitative workload, neuroticism and self-blaming, while the protective factors included: age, social support, and extraversion [49]. The risk factors in the second group encompassed the following: quantitative workload, neuroticism, conflict with a physician, behavioral disengagement, with the only protective factor being social support [49]. The protective factor within the patient-related group referred to the conflict of professional roles, while the risk factors included the following: conflict with a patient, quantitative workload, neuroticism, and behavioral disengagement [49]. On the other hand, burnout is a risk factor for making a decision to quit employment [50].

Burnout means failure in the existential quest to find meaning in the performed work. It most commonly develops in individuals with high ambitions and professional expectations, who are willing to take up work and identify themselves to a great extent with professional problems. Individuals most vulnerable to burnout include those whose 
strong motivation and professional activities are not recognized [51].

A promising tool for the development of patient cooperation is offered by coaching, which has been described in the subsequent paragraph.

The first report on coaching appeared in scientific literature in the first half of the $20^{\text {th }}$ century [Gorby, 1937; as cited in: 52]. There has also been a growing trend in the number of publications on the subject, especially within the last decades [52].

The aim of coaching is to accompany the process of change, to relize the potential in order to allow the coachee to achieve his/her intended goals [53]. According to the definition proposed by Anthony Grant, personal coaching (or life coaching) is: “ $\ldots$ a solution-focused, resultsorientated systematic process in which the coach facilitates the enhancement of the coachee's life experience and performance in various domains (as determined by the coachee), and fosters the selfdirected learning and personal growth of the coachee" [54]. On the other hand, workplace coaching is defined as: “... a solution-focused, result-orientated systematic process in which the coach facilitates the enhancement of work performance and the self-directed learning and personal growth of the coachee" [54].

Another definition proposed by the largest international organization of coaching professionals, namely the International Coach Federation (ICF), whose Code of Ethics provides that: "Coaching is partnering with clients in a thought-provoking and creative process that inspires them to maximise their personal and professional potential" [55].

Numerous authors indicate the possibility of applying coaching in the area of health [56,57,58]. According to Palmer and his team, health coaching is: ". the practice of health education and health promotion within a coaching context, to enhance the wellbeing of individuals and to facilitate the achievement of their health-related goals" [5].

Working with a coach potentially translates into positive results, and therefore it is worth considering this method as an element of support for medical personnel and patients [inter alia: 5]. Coaching can be successfully taken advantage of by the health sciences $[59,60]$ and medical sciences [inter alia: 27,61,62], to name only a few. Health coaching frequently appears in the context of research on a group of chronically ill patients [inter alia: 63-66]. Its efficacy has also been confirmed in relation to elderly people [67]. This intervention is also used for medical personnel $[68,69]$. It is also mentioned in the context of medical education [70].

Table 1. The effects of coaching described in the literature

\begin{tabular}{|c|c|c|c|}
\hline Publication & $\begin{array}{c}\text { Medical } \\
\text { profession }\end{array}$ & Specificity of the job & Effects of coaching \\
\hline $\begin{array}{l}\text { van Mierlo, Meiland } \\
\text { \& Dröes (2012) } \\
\text { [74] }\end{array}$ & \begin{tabular}{|l|} 
Informal \\
caregivers \\
of \\
dementia \\
patients
\end{tabular} & $\begin{array}{l}\text { Caregivers are observed to } \\
\text { experience high levels of stress, } \\
\text { depression and burden }\end{array}$ & $\begin{array}{l}\text { 1. Telecoaching in combination } \\
\text { with institutional support (day care } \\
\text { units) reduced the burden and } \\
\text { incidence of health problems } \\
\text { among informal caregivers of } \\
\text { dementia patients }\end{array}$ \\
\hline $\begin{array}{l}\text { Aboalshamat, Hou, \& } \\
\text { Strodl (2013) } \\
{[75]}\end{array}$ & $\begin{array}{l}\text { Medical } \\
\text { and } \\
\text { dental } \\
\text { students }\end{array}$ & $\begin{array}{l}\text { Psychological health } \\
\text { disturbances, high levels of } \\
\text { stress, depression and anxiety - } \\
\text { confirmed by examination }\end{array}$ & $\begin{array}{l}\text { 2. Significant improvement in } \\
\text { mental health (among others, in the } \\
\text { area of depression, the sense of } \\
\text { self-efficacy and satisfaction with } \\
\text { life) }\end{array}$ \\
\hline $\begin{array}{l}\text { Schneider, Kingsolver } \\
\& \text { Rosdahl (2014) } \\
\text { [76] }\end{array}$ & Physicians & Exposure to stress & $\begin{array}{l}\text { 3. Greater resistance to stress, } \\
\text { indirect positive effect on patient } \\
\text { care }\end{array}$ \\
\hline $\begin{array}{l}\text { Gazelle et al. (2014) } \\
\text { [27] }\end{array}$ & Physicians & Exposure to burnout & $\begin{array}{l}\text { 4. Improved functioning, extended } \\
\text { self-awareness, increased mental } \\
\text { resilience }\end{array}$ \\
\hline $\begin{array}{l}\text { Palamara, Kauffman, } \\
\text { Stone, Bazari, \& } \\
\text { Donelan (2015) } \\
\text { [77] }\end{array}$ & $\begin{array}{l}\text { Physicians } \\
\text { and } \\
\text { residents }\end{array}$ & $\begin{array}{l}\text { Limited support for residents, } \\
\text { lack of experience, long } \\
\text { working hours, time pressure, } \\
\text { exaggerated stress reactions are } \\
\text { conducive to burnout. }\end{array}$ & $\begin{array}{l}\text { 5. Less emotional exhaustion and } \\
\text { burnout among residents. Positive } \\
\text { assessment of the coaching program }\end{array}$ \\
\hline $\begin{array}{l}\text { Fares et al. (2016) } \\
{[28]}\end{array}$ & $\begin{array}{l}\text { Medical } \\
\text { students }\end{array}$ & $\begin{array}{l}\text { A high level of stress related to } \\
\text { studies. Exposure to burnout }\end{array}$ & $\begin{array}{l}\text { 6. Reducing the incidence of stress } \\
\text { and burnout by influencing stress- } \\
\text { coping methods }\end{array}$ \\
\hline
\end{tabular}


The effects of coaching have been summarized in the table above (Table 1). Attention has been drawn to the specificity of the work performed by the representatives of medical professions. Moreover, the effects of coaching has been presented with regard to informal caregivers as a group which is exposed not merely to a physical but also a mental burden [71-73]. What is striking is the lack of publications concerning the application of urse-oriented coaching, the objective of which would be to reduce the risk of burnout.

\section{CONCLUSIONS}

Burnout is a rapidly growing problem that affects medical professionals. It affects not only the employees themselves but also the patients. It is therefore appropriate to undertake preventive actions as soon as possible in order to reduce the probability of burnout. One such action is medical coaching, which played an increasingly influential role in the field of health sciences [inter alia: $13,59,60]$ and medicine [inter alia: 27,61,62,78]. De Souza and Viney [78] note that this element is necessary in medicine.

The majority of research concerning coaching as a method potentially reducing the risk of burnout (see Table 1) encompassed physicians as well as medical and dental students. This group is observed to experience high levels of stress and burden $[28,75,76]$.

It seems that health/medical coaching can be an effective intervention that reduces the risk of burnout in a group of medical professionals. There is no doubt that further research is necessary in order to verify the efficacy of coaching as a form of education and strengthening the motivation of medical personnel. In the group of medical professionals, the individuals running the highest risk of negative consequences are nurses, who - due to the specific nature of their job - struggle with a high emotional burden. It seems that they should be the primary target of coaching programs. However, it is difficult to clearly indicate the efficacy of coaching among nurses. The reason for this is that the issue first needs to be explored. It still remains an open question whether a coaching program targeted at a specific group of medical professions, such as nurses, should be more universal, concentrating on concrete skills and needs of the entire professional group, or whether it should be dedicated to given specializations, for example nurses working in psychiatry, hospices, palliative care units, admission rooms, or intensive care units. This is related to a significant problem of a practical nature, because the individualization of programs entails higher costs. On the other hand, the results could potentially be more effective.

\section{Conflicts of interests}

There are no conflicts of interests regarding the publication of this article.

\section{REFERENCES}

1. Butterworth SW, Linden A, McClay W. Health coaching as an intervention in health management programs. Dis Manag Health Out 2007 Nov;15(5):299-307.

2. Hill B, Richardson B, Skouteris H. Do we know how to design effective health coaching interventions: a systematic review of the state of the literature. Am J Health Promot 2015 May;29(5):e158-e68.

3. Olsen JM, Nesbitt BJ. Health coaching to improve healthy lifestyle behaviors: an integrative review. Am J Health Promot 2010 Sep;25(1):e1-e12.

4. Wolever RQ, Dreusicke M, Fikkan J, Hawkins TV, Yeung S, Wakefield J, Skinner E. Integrative health coaching for patients with type 2 diabetes a randomized clinical trial. Diabetes Educator 2010 Jun;36(4):629-39.

5. Palmer S, Tubbs I, Whybrow A. Health coaching to facilitate the promotion of healthy behaviour and achievement of health-related goals. Int J Health Prom Edu 2003;41(3):913.

6. Lonie JM, Austin Z, Nguyen R, Gill I, Tsingos-Lucas C. Pharmacist-based health coaching: A new model of pharmacist-patient care. SJR 2017 May-Jun;13(3):644-52.

7. Sherifali D, Viscardi V, Bai JW, Ali RMU. Evaluating the Effect of a Diabetes Health Coach in Individuals with Type 2 Diabetes. Can J Diabetes 2016 Feb; 40(1):84-94.

8. Linden A, Butterworth SW, Prochaska JO. Motivational interviewing-based health coaching as a chronic care intervention. J Eval Clin Pract 2010 Feb;16(1):166-74.

9. Thom DH, Hessler D, Willard-Grace R, Bodenheimer T, Najmabadi A, Araujo C, Chen EH. Does health coaching change patients' trust in their primary care provider? Patient Educ Couns 2014 Jul; 96(1):135-8.

10. Benzo R, Vickers Douglas K, Novotny PJ, Tucker S, Hoult J, Neuenfeldt P, McEvoy C. Health coaching and COPD rehospitalization: a randomized study. In $A 23$. Understanding and reducing COPD rehospitalizations. 2016 (pp. A1116-A1116). American Thoracic Society.

11. Baek M, Jang KS. Development and Verification on the Effectiveness of Coaching Program for Nurses. J Health Inform Stat 2016 Feb;41(1):57-66.

12. Purba J, Suttharangsee W, Chaowalit A. Effectiveness of a Coaching Program for Family Caregivers of Persons with Schizo- 
phrenia: A Randomized Controlled Trial. WJST 2016;14(1):11-24.

13. Ekim A. A growing trend in pediatric nursing: coaching. J Nurs Care 2015;1(2):006.

14. Ickes MJ, McMullen J. Evaluation of a health coaching experimental learning collaboration with future health promotion professionals. PHP 2016 May;2(3):161-9.

15. Sęk H. Pomoc psychologiczna w rozwiązywaniu problemów zdrowotnych. In: Sęk H, editor. Psychologia kliniczna. Warszawa: PWN; 2013. p. 246-55. (Polish)

16. Maslach C, Schaufeli WB, Leiter MP. Job burnout. Annual review of psychology. 2001; 52(1):397-422.

17. Squires A, Finlayson C, Gerchow L, Cimiotti JP, Matthews A, Schwendimann R, MorenoCasbas MT. Methodological considerations when translating "burnout". Burnout research 2014 Sep;1(2):59-68.

18. Leiter MP, Maslach C. Latent burnout profiles: A new approach to understanding the burnout experience. Burnout Research 2016 Dec;3(4):89-100.

19. Pereira SM, Teixeira CM, Carvalho AS, Hernández-Marrero P. Compared to Palliative Care, Working in Intensive Care More than Doubles the Chances of Burnout: Results from a Nationwide Comparative Study. PloS one. 2016 Sep;11(9),e0162340.

20. Grant AM. Solution-focused cognitivebehavioral coaching for sustainable high performance and circumventing stress, fatigue, and burnout. Consult Psychol J Pract Res 2017;69(2):98-111.

21. Maslach C. Finding solutions to the problem of burnout. Consult Psychol J Pract Res 2017;69(2):143-52.

22. Galián-Muñoz I, Ruiz-Hernández JA, LlorEsteban B, López-García C. User violence and nursing staff burnout: The modulating role of job satisfaction. J Interpers Violence 2016 Nov;31(2):302-15.

23. Frydrysiak K, Grześkowiak M, Podlewski R. Agresja pacjentów zagrożeniem w pracy zespołów ratownictwa medycznego. Anest Ratow 2014;8(4):381-91. (Polish)

24. Lewandowska A, Litwin B. Wypalenie zawodowe jako zagrożenie $w$ pracy pielęgniarki. Ann Acad Med Stetin 2009;55 (3):86-9. (Polish)

25. Uchmanowicz I, Jankowska-Polańska B, Bronowicka G. Zjawisko wypalenia zawodowego wśród pielęgniarek pracujących na oddziałach onkologicznych - badanie wstępne. Probl Pielęg 2013;21(4):476-83. (Polish)

26. Askin WJ. Coaching for physicians Building more resilient doctors. Can Fam Physician 2008 Oct;54(10):1399-400.
27. Gazelle G, Liebschutz JM, Riess H. Physician burnout: coaching a way out. J Gen Intern Med 2014 Dec;30(4):508-13.

28. Fares J, Al Tabosh H, Saadeddin Z, El Mouhayyar C, Aridi H. Stress, burnout and coping strategies in preclinical medical students. North Am J Med Sci 2016 Feb;8(2): 75-81.

29. The Act of 15 April 2011 on medical activity; Dz.U. [Journal of Laws] 2011, No. 112, Item 654, Art. 2

30. Kędra E, Sanak K. Stres i wypalenie zawodowe w pracy pielęgniarek. Piel Zdr Publ 2013;3(2):119-32. (Polish)

31. Kowalczuk K, Zdańska A, Krajewska-Kułak E, Łukaszuk C, Van Damme-Ostapowicz K, Klimaszewska K, Rozwadowska E. Stres w pracy pielęgniarek jako czynnik ryzyka wypalenia zawodowego. Probl Pielęg 2011; 19(3):307-14. (Polish)

32. Wzorek A. Porównanie przyczyn stresu wśród pielęgniarek pracujących na oddziałach o różnej specyfice. Studia Medyczne. 2008;11: 33-7. (Polish)

33. Kowalczyk M. Poczucie straty i uczucia utajone $\mathrm{W}$ pracy $\mathrm{z}$ pacjentem terminalnie chorym. Med Paliat Prakt 2010;4(1):1-4. (Polish)

34. Kowalczyk M. Wypalenie zawodowe w pracy $\mathrm{z}$ terminalnie chorym pacjentem. Med Paliat Prakt 2011;4(4):154-8. (Polish)

35. Kowalczuk K, Jankowiak, B, KrajewskaKułak E， Sierakowska, M, Lewko, J, Krajewska K, Ostapowicz-Van Damme, K. Ocena stopnia narażenia ratowników medycznych na agresję w miejscu pracy. Ann Acad Med Stetin 2009;55(3):76-80. (Polish)

36. Nyklewicz W, Krajewska-Kułak E. Śmierć a emocje pielęgniarek - doniesienie wstępne. Probl Pielęg 2008;16(3):248-54. (Polish)

37. Fopka-Kowalczyk MJ. Wsparcie oczekiwane przez pracowników opieki paliatywnej $\mathrm{w}$ kontekście poczucia straty po śmierci pacjentów. Med Paliat 2015;7(2):122-9. (Polish)

38. Grau-Alberola E, Gil-Monte PR, GarcíaJuesas JA, Figueiredo-Ferraz H. Incidence of burnout in Spanish nursing professionals: A longitudinal study. IJNS, 2010 Aug;47(8): 1013-20.

39. Jourdain G, Chênevert D. Job demandsresources, burnout and intention to leave the nursing profession: A questionnaire survey. IJNS 2010 Jun;47(6):709-22.

40. Wrzesińska M, Krukowska J, Rasmus P, Wicherska K. Wypalenie zawodowe a zmienne demograficzne i psychospołeczne $u$ aktywnych zawodowo fizjoterapeutów. Zdrowie Publiczne i Zarządzanie. 2015;13(3): 295-301. 
41. Mickiewicz K, Babska A, Günther-Jabłońska A, Głogowska K. Wypalenie zawodowe asystentów rodziny a kompetencje społeczne i strategia radzenia sobie ze stresem. Praca Socjal 2016;31(2):165-88. (Polish)

42. Hackett A, Palmer S. An investigation into the perceived stressors for staff working in the hospice service. Int J Palliat Nurs 2010 Jun; 16(6):290-6.

43. Maslach C. Wypalenie $\mathrm{w}$ perspektywie wielowymiarowej. In: Sęk $\mathrm{H}$, editor. Wypalenie zawodowe: przyczyny i zapobieganie. Warszawa: PWN; 2009, p. 1331. (Polish)

44. Maslach C, Leiter MP. Understanding the burnout experience: recent research and its implications for psychiatry. World Psychiatry 2016 Jun;15(2):103-11.

45. Perlman B, Hartman EA. Burnout: Summary and future research. Hum Relat 1982 Apr;35 (4):283-305.

46. Burisch M. W poszukiwaniu teoriiprzemyślenia na temat natury $\mathrm{i}$ etiologii wypalenia. In: Sęk H, Ed.. Wypalenie zawodowe: przyczyny i zapobieganie. Warszawa: PWN; 2009, p. 56-83. (Polish)

47. Sęk H. Uwarunkowania i mechanizmy wypalenia zawodowego w modelu społecznej psychologii poznawczej. In: Sęk $\mathrm{H}$, editor. Wypalenie zawodowe: przyczyny i zapobieganie. Warszawa: PWN; 2009, p. 83112. (Polish)

48. Kandelman N, Mazars T, Levy A. Risk factors for burnout among caregivers working in nursing homes. J Clin Nurs 2017 Jul;00: 1-7.

49. Shimizutani M, Odagiri Y, Ohya Y, Shimomitsu T, Kristensen TS, Maruta T, Iimori M. Relationship of nurse burnout with personality characteristics and coping behaviors. Industrial health. 2008;46(4):32635.

50. Heinen MM, van Achterberg T, Schwendimann R, Zander B, Matthews A, Kózka M, Schoonhoven L. Nurses' intention to leave their profession: a cross sectional observational study in 10 European countries. IJNS 2013 Feb; 50(2):174-84.

51. Mojs E, Głowacka D. Wypalenie zawodowe u polskich pielęgniarek. Now Lek 2005;74(2): 238-43. (Polish)

52. Spence GB, Grant AM. Coaching and wellbeing: A brief review of existing evidence, relevant theory and implications for practitioners. In book: Editors: David S, Boniwell I, Conley A, editors. The Oxford Handbook of Happiness, Edition: First, Publisher: Oxford University Press, 2012; p. 1009-25.

53. Spence GB, Grant AM. Professional and peer life coaching and the enhancement of goal striving and well-being: An exploratory study. J Positive Psychol 2007 Jun;2(3):185-94.

54. Grant AM. Towards a psychology of coaching: The Impact of Coaching on Metacognition, Mental Health and Goal Attainment. Unpublished doctoral dissertation, Sydney, 2001. Available from: http://www. eric.ed.gov/PDFS/ED478147.pdf

55. ICF Code of Ethics [cited 2017 July 19]. Available from: https://icf.org.pl/o-icf/2960-2/

56. Palmer S. Health coaching: A developing field within health education. Health Edu J 2004 Jun;63(2):189-91.

57. Gyllensten K, Palmer S. The relationship between coaching and workplace stress: A correlational study. Int J Health Prom Edu 2005;43(3):97-103.

58. Michalski P, Kosobucka A, Nowik M, Pietrzykowski $Ł$, Andruszkiewicz A, Kubica A. Edukacja zdrowotna pacjentów $\mathrm{z}$ chorobami układu sercowo-naczyniowego. Folia Cardiol 2016;11(6):519-24. (Polish)

59. Piamjariyakul U, Werkowitch M, Wick J, Russell C, Vacek JL, Smith CE. Caregiver coaching program effect: Reducing heart failure patient rehospitalizations and improving caregiver outcomes among African Americans. Heart \& Lung 2015 Nov-Dec; 44(6):466-73.

60. Wang CJ, Fetzer SJ, Yang YC, Wang JJ. The impacts of using community health volunteers to coach medication safety behaviors among rural elders with chronic illnesses. Geriatric Nursing. 2013 Mar-Apr;34(2):138-45.

61. O'Hara BJ, Gale J, McGill B, Bauman A, Hebden L, Allman-Farinelli M, Phongsavan P. Weight-Related Goal Setting in a TelephoneBased Preventive Health-Coaching Program Demonstration of Effectiveness. Am J Health Promot 2016 Aug;0890117116660776.

62. Schwellnus H, King G, Thompson L. Clientcentred coaching in the paediatric health professions: a critical scoping review. Disabil Rehabil 2014 Oct;37(15):1305-15.

63. Fehily C, Bartlem K, Wiggers J, Wye P, Clancy R, Castle D, Murphy F. Evaluating the effectiveness of a healthy lifestyle clinician in addressing the chronic disease risk behaviours of community mental health clients: study protocol for a controlled trial. Trials. 2017 Jun;18(1):276.

64. Oksman E, Linna M, Hörhammer I, Lammintakanen J, Talja M. Cost-effectiveness analysis for a tele-based health coaching program for chronic disease in primary care. BMC health services research. 2017 Feb; 17(1):138.

65. Huang B, Willard-Grace R, De Vore D, Wolf J, Chirinos C, Tsao S, Thom DH. Health coaching to improve self-management and 
quality of life for low income patients with chronic obstructive pulmonary disease (COPD): protocol for a randomized controlled trial. BMC Pulm Med 2017 Jun;17: 90.

66. Boehmer KR, Barakat S, Ahn S, Prokop LJ, Erwin PJ, Murad MH. Health coaching interventions for persons with chronic conditions: a systematic review and metaanalysis protocol. Systematic reviews 2016 Sep;5(1): 146 .

67. Oliveira JS, Sherrington C, Amorim AB, Dario AB, Tiedemann A. What is the effect of health coaching on physical activity participation in people aged 60 years and over? A systematic review of randomised controlled trials. Br J Sports Med 2017; Oct; 51(19):1425-32.

68. Gallagher E, Moore A, Schabort I. Leadership training in a family medicine residency program. Can Fam Physician 2017 Mar; 63(3):e186-e192.

69. Djuric Z, Segar M, Orizondo C, Mann J, Faison M, Peddireddy N, Locke A. Delivery of Health Coaching by Medical Assistants in Primary Care. J Am Board Fam Med 2017 May-Jun;30(3):362-70.

70. Deiorio NM, Carney PA, Kahl LE, Bonura EM, Juve AM. Coaching: a new model for academic and career achievement. Medical education online. 2016; 21(1):33480.

71. Hansen L, Lyons KS, Dieckmann NF, Chang MF, Hiatt S, Solanki E, Lee CS. Background and design of the symptom burden in endstage liver disease patient-caregiver dyad study. Res Nurs Health. 2017 Oct;40(5):398413.
72. Castellano-Tejedor C, Lusilla-Palacios P. A study of burden of care and its correlates among family members supporting relatives and loved ones with traumatic spinal cord injuries. Clin Rehabil 2017 Jun; 31(7):948-56.

73. Yu Y, Liu Z-w, Tang B-w, Zhao M, Liu X-g, Xiao S-y. Reported family burden of schizophrenia patients in rural China. PloS One. 2017 Jun;12(6):e0179425.

74. van Mierlo LD, Meiland FJ, Dröes RM. Dementelcoach: effect of telephone coaching on carers of community-dwelling people with dementia. Int Psychogeriatrics 2012 Feb; 24(02): 212-222.

75. Aboalshamat K, Hou XY, Strodl E. Improving dental and medical students' psychological health using a self-development coaching program: A pilot study. JAMR 2013;3(3):4557.

76. Schneider S, Kingsolver K, Rosdahl J. Physician coaching to enhance well-being: a qualitative analysis of a pilot intervention. Explore (NY) 2014 Nov-Dec;10(6):372-9.

77. Palamara K, Kauffman C, Stone VE, Bazari H, Donelan K. Promoting success: a professional development coaching program for interns in medicine. JMGE 2015 Dec;7(4): 630-7.

78. De Souza B, Viney R. Coaching and mentoring skills: necessities for today's doctors. BMJ Careers. 2014 Jun; http://care ers.bmj.com/careers/advice/viewarticle.html?i $\mathrm{d}=20018242$ [cited 6 March 2017]. 